\title{
Differentiation of Bacillus anthracis and other Bacillus cereus group bacterial strains using multilocus sequence typing method
}

\author{
GRZEGORZ GRANIAK (D) ${ }^{1}$, ALINA OLENDER (iD ${ }^{2}$, KATARZYNA NAYLOR (D) ${ }^{3}$ \\ ${ }^{1}$ General Karol Kaczkowski Military Institute of Hygiene and Epidemiology, Biological Threats \\ Identification and Countermeasure Centre, Lubelska 4, 24-100 Pulawy, Poland \\ ${ }^{2}$ Medical University in Lublin, Department of Medical Microbiology, Chódzki 1, 20-093 Lublin, Poland \\ ${ }^{3}$ Medical University in Lublin, Department of Didactics and Medical Simulation, Chódzki 4, 20-093 Lublin, \\ Poland \\ E-mail: grzegorz.graniak@gmail.com
}

\begin{abstract}
The study describes the preparation of the phylogenetic differentiation of Bacillus cereus strains. The Bacillus cereus group of bacteria is very important for human and animal health. The multilocus sequence typing scheme has been used to present this group of bacteria's phylogenetic relationship and structure. The MLST system was established using 60 isolates of B. anthracis, B. cereus sensu stricto, B. thuringiensis, and transitional environment strains of Bacillus spp. As a negative control, five strains of $B$. subtilis and B. megaterium were used. Primers for amplification and sequencing were designed to target highly conserved internal fragment of seven housekeeping genes: $g l p F, g m k, i l v D, p t a, p u r$, pycA, and tpi. A total of 22 different sequence types (STs) were distinguished. Analysis of the sequence data showed that all of the Bacillus cereus strains are very closely related. The MLST scheme exhibited a high level of resolution that can be used as an excellent tool for studying the phylogenetic relationship, epidemiology, and population structure of the Bacillus cereus group strains. The MLST method additionally allows us to define the phylogenetic relationship between very closely related strains based on a combination of the sequences of all seven alleles fragments and each of them separately. Thus, this genetic investigation tool is very useful in epidemiological investigation of potential military/ bioterrorist use of $B$. anthracis.
\end{abstract}

KEYWORDS: Bacillus cereus group, multilocus sequence typing, sequencing, housekeeping genes, phylogenetic differentiation, BioNumerics

\section{Introduction}

Bacterial strains from the Bacillus comprises six species of bacteria: cereus group belong to the Bacillaceae B. anthracis, B. cereus, B. thuringiensis, family (Ludwig et al. 2009). This group

$B$. weihenstephanensis, B. mycoides, and 
B. pseudomycoides, which are very important for medical (biological) and economic reasons. The Bacillus cereus group contains nonpathogenic strains found in humans and animals (saprophytic environmental strains), industrial use strains, and very pathogenic strains, which can be used as a biological weapon agent. B. cereus is an opportunistic human pathogen commonly present in soil and water. Due to its ubiquitous nature, $B$. cereus can cause contamination in the pulp and paper and the dairy industry. Additionally, B. cereus strains can cause various infections in immunodeficient patients and patients after surgery, including endocarditis, cutaneous infections, septicemia, pneumonia (Hoffmaster et al. 2006), or emetic and diarrheal food poisoning (Kim et al. 2010). B. thuringiensis is a pathogen for insects Diptera sp., Lepidoptera, and Coleoptera sp. (Elleuch et al. 2014) and an opportunistic pathogen for human. B. thuringiensis is used in agriculture as a source of natural insecticides in tomatoes, cucumbers, or cabbages cultivation (Frederiksen et al. 2006). B. weihenstephanensis has been described recently due to its ability to grow in very low temperatures $\left(+4^{\circ} \mathrm{C}\right.$ to $\left.+7^{\circ} \mathrm{C}\right)$. As a separate species in the Bacillus cereus group, it was identified based on the 16S rRNA and cold-shock protein gene $\operatorname{csp} A$ sequences (Thorsen et al. 2006). Additionally, some strains of B. weihenstephanensis possess genes for enterotoxin NheA and emetic toxin cereulide (Svensson et al. 2007; Økstad and Kolstø 2011), like B. cereus. For $B$. mycoides and B. pseudomycoides strains, a different rhizoidal type of growth was observed (Sorokin et al. 2006). B. anthracis is a Gram-positive, spore-forming, aerobic, rod-shaped bacterium. It is the most dangerous human and animal pathogen, causes the very high lethality zoonotic disease anthrax, which can be acquired in four ways: inhalation (50-80\% mortality even with treatment), cutaneous, gastrointestinal, and injection. The pathogenicity of $B$. anthracis depends on two virulent factors encoded by genes located on two plasmids pXO1 (anthrax toxin) and pXO2 (poly- $\gamma$-d-glutamic acid capsule) (Brossier and Mock 2001; Gierczyński 2010). Changes in the genome (addition or loss of the pathogenicity) can result from the conjugation (horizontal gene transfer) process, which has been described in Bacillus strains (Singh et al. 2013). Owing to its spores being very easy to produce, transport, and disperse, B. anthracis is potentially useful as a biological warfare agent, classified as a group of dangerous pathogens by the Centers for Disease Control and Prevention (2017).

Numerous methods have been used to perform genetic differentiation of Bacillus cereus group strains. Recently, the most popular were: restriction enzyme analysis - pulsed-field gel electrophoresis (REA-PFGE) (Helgason et al. 2000b; Tenover et al. 1995, 1997), amplified fragment length polymorphism (AFLP) (DeVos et al. 1995; Ticknoe et al. 2001), 16S and 23S rRNA analysis (Cherif et al. 2003; Soufiane and Côté 2013), and multilocus enzyme electrophoresis (MEE) (Helgason et al. 2000a; Selander et al. 1986). Even though those methods are advantageous, the results are very arduous to standardise and compare among different laboratories. In 1998 Maiden's team developed a novel molecular method based on sequencing internal fragments of the chromosome, enabling genetic characterisation of multiple bacterial strains in one experiment (Maiden et al. 1998).

Multilocus sequence typing is based on the analysis of nucleotide sequences of highly conserved fragments of a few housekeeping genes. Since 1998, the 
MLST scheme was developed for several human bacterial pathogens including: Clostridium botulinum (Olsen et al. 2014), Clostridium difficile (Zhou Y. et al. 2014), Corynebacterium diphtheriae (Bolt et al. 2010), Vibrio cholera (Zhou H. et al. 2014), Yersinia sp. (Duan et al. 2014; Souza et al. 2013), Bordetella sp. (Diavatopoulos et al. 2005), Haemophilus influenzae (Skaare et al. 2014), and Streptococcus pneumoniae (Chang et al. 2014).

In this study, the MLST scheme for genetic differentiation and characterisation of Bacillus cereus group strains from the internal collection of the Biological Threats Identification and Countermeasure Centre of Military Institute of Hygiene and Epidemiology in Pulawy (BTICC MIHE) was performed.

\section{Materials and methods}

A total of 65 bacterial strains were analysed. Sixty of them were from the Bacillus cereus group strains, and five strains of B. subtilis and B. megaterium were used as negative control samples. All of them were part of an internal collection of the BTICC MIHE (obtained from the Institute of Medicine and Molecular Biology (IMBM) at the University of Scranton, Pennsylvania, USA; Veterinary Inspection, Łomża, Poland, Medical University of Lublin, Poland, and from the environment isolated by BTICC specialists) and have been identified before by various methods (microscopy, biochemical, immunological, PCR, real-time PCR, etc.) (Cieślik et al. 2015). The strains were isolated from animals, people, and the worldwide environment (Germany, China, France, USA). Tested groups of bacterial strains included 10 strains of B. cereus, 17 B. thuringiensis, seven $B$. anthracis, and 26 transitional environmental Bacillus sp. strains. Transitional strains gave positive results in the PCR reaction for $B$. anthracis chromosomal marker $B a 813+$. The analysed strains are shown in Table 1.

This study includes selected fragments of seven housekeeping genes. The following genes were chosen: $g l p F$ (encoding glycerol uptake facilitator protein), gmk (guanylate kinase), ilvD (dihydroxy-acid dehydratase), pta (phosphate acetyltransferase), pur (AICAR transformylase), $p y c A$ (pyruvate carboxylase), and tpi (triosephosphate isomerase) (Priest et al. 2004). The primers used for amplification and sequencing of these fragments are shown in Table 2.

The primers were synthesised by Genomed JSC Poland, based on the sequence from the PubMLST Database (primers used for MLST of Bacillus genes) (PubMLST 2018).

The genetic material was isolated from fresh bacterial culture using the automatic isolation station QIAcube ${ }^{\circledR}$ (QiaGene Corp. ${ }^{\circledR}$ ) using the QIAamp DNA Mini Kit (QiaGene Corp. $\left.{ }^{\circledR}\right)$, according to the manufacturer's instructtions. Fresh cultures of tested strains were prepared on Columbia Agar plates containing 5\% sheep blood (Graso Biotech, Poland), incubated at $37^{\circ} \mathrm{C}$ for 24 hours under aerobic conditions. After incubation, the selected colonies (after morphological and microscopy evaluation) were transferred to the buffer from the isolation kit.

The amplification reactions were performed in a volume of $50 \mu \mathrm{l}$ for 45 cycles. Reaction mixtures consisted of $5 \mu \mathrm{l}$ of dNTP mix (starting concentration $2 \mathrm{mM}$ each dNTP), $1 \mu \mathrm{l}$ of each primer (starting concentration $10 \mathrm{mM}$ ), $5 \mu \mathrm{l}$ of 10x PfuUltra II reaction buffer, $1 \mu$ of PfuUltra II fusion HS DNA polymerase (Agilent Inc. $($ ), and $50 \mathrm{ng}$ of genomic DNA. The thermal profile comprised of the following steps: initial denaturation at $94^{\circ} \mathrm{C}$ for $1 \mathrm{~min}$, denaturation at $94^{\circ} \mathrm{C}$ for 
Table 1. The analysed strains of Bacillus sp.

\begin{tabular}{|c|c|c|}
\hline No. & Species & Strain \\
\hline 1. & B. cereus & ATCC 10876 \\
\hline 2. & B. cereus & ATCC 13472 \\
\hline 3. & B. cereus & ATCC 19637 \\
\hline 4. & B. cereus & ATCC 23261 \\
\hline 5. & B. cereus & F 17202 \\
\hline 6. & B. cereus & F 17285 \\
\hline 7. & B. cereus & $\mathrm{T} 7-101$ \\
\hline 8. & B. cereus & UM1 \\
\hline 9. & B. cereus & UM2 \\
\hline 10. & B. cereus & UW 85 \\
\hline 11. & B. thuringiensis & ATCC 10792T \\
\hline 12. & B. thuringiensis & ATCC 33679 \\
\hline 13. & B. thuringiensis & T07-128 \\
\hline 14. & B. thuringiensis & H36 \\
\hline 15. & B. thuringiensis & T 07-001 \\
\hline 16. & B. thuringiensis & Т 07-005 \\
\hline 17. & B. thuringiensis & Т 07-019 \\
\hline 18. & B. thuringiensis & T 07-113 \\
\hline 19. & B. thuringiensis & Т 07-146 \\
\hline 20. & B. thuringiensis & T 07-148 \\
\hline 21. & B. thuringiensis & T 07-153 \\
\hline 22. & B. thuringiensis & T 7-030 \\
\hline 23. & B. thuringiensis & T 7-055 \\
\hline 24. & B. thuringiensis & T 7-101 \\
\hline 25. & B. thuringiensis & T 7-128 \\
\hline 26. & B. thuringiensis & T07-151 \\
\hline 27. & B. thuringiensis & T07-155 \\
\hline 28. & B. anthracis & 1153 \\
\hline 29. & B. anthracis & 1582 \\
\hline 30. & B. anthracis & 1583 \\
\hline 31. & B. anthracis & 1584 \\
\hline 32. & B. anthracis & 211 \\
\hline 33. & B. anthracis & $211 Y$ \\
\hline
\end{tabular}

\begin{tabular}{|c|c|c|}
\hline No. & Species & Strain \\
\hline 34. & B. anthracis & $34 \mathrm{~F} 2$ \\
\hline 35. & B. sp. Ba $813+$ & \#11 (9594(3) \\
\hline 36. & B. sp. Ba $813+$ & $\# 12 / \mathrm{S} 8553(2)$ \\
\hline 37. & B. sp. Ba $813+$ & $\# 13$ (PC1) \\
\hline 38. & B. sp. Ba $813+$ & \#14 \\
\hline 39. & B. sp. Ba $813+$ & \#15 (11614-2) \\
\hline 40. & B. sp. Ba $813+$ & \#16 (PJ572) \\
\hline 41. & B. sp. Ba $813+$ & \#17 (094) \\
\hline 42. & B. sp. Ba $813+$ & \#19 (T579-77) \\
\hline 43. & B. sp. Ba $813+$ & \#21 (TII97-3) \\
\hline 44. & B. sp. Ba $813+$ & $\# 22$ \\
\hline 45. & B. sp. Ba $813+$ & $\# 22(\mathrm{Br}-13)$ \\
\hline 46. & B. sp. Ba $813+$ & \#23 (III-4) \\
\hline 47. & B. sp. Ba $813+$ & \#24 (II/B5) \\
\hline 48. & B. sp. Ba $813+$ & $\# 25$ (97-27) \\
\hline 49. & B. sp. Ba $813+$ & \#28 (II) \\
\hline 50. & B. sp. Ba $813+$ & \#28 (III) \\
\hline 51. & B. sp. Ba $813+$ & $\# 29$ (IV) \\
\hline 52. & B. sp. Ba $813+$ & $\# 30$ (1B) \\
\hline 53. & B. sp. Ba $813+$ & $\# 31$ \\
\hline 54. & B. sp. Ba $813+$ & $\# 25$ (97-24) \\
\hline 55. & B. sp. Ba $813+$ & \#6 \\
\hline 56. & B. sp. Ba $813+$ & \#S8553/2 \\
\hline 57. & B. sp. Ba $813+$ & \#7 (II/3) \\
\hline 58. & B. sp. Ba $813+$ & C9A \\
\hline 59. & B. sp. Ba $813+$ & Z 5 (1) Miazga \\
\hline 60. & B. sp. Ba $813+$ & ZL 2 B \\
\hline 61. & B. subtilis & ATCC 6633 \\
\hline 62. & B. subtilis & UM1 \\
\hline 63. & B. subtilis & UM2 \\
\hline 64. & B. megaterium & UM1 \\
\hline 65. & B. megaterium & UM2 \\
\hline
\end{tabular}

Table 2. The primers used for amplification and sequencing chosen genes

\begin{tabular}{|l|l|l|}
\hline$g l p F:$ & F - 5'GCGTTTGTGCTGGTGTAAGT3', & R - 5'CTGCAATCGGAAGGAAGAAG3'; \\
\hline$g m k:$ & F - 5'ATTTAAGTGAGGAAGGGTAGG3', & R - 5'GCAATGTTCACCAACCACAA3'; \\
\hline ilvD: $^{\prime}$ & F - 5'CGGGGCAAACATTAAGAGAA3', & R - 5'GGTTCTGGTCGTTTCCATTC3'; \\
\hline pta: & F - 5'GCAGAGCGTTTAGCAAAAGAA3', & R - 5'TGCAATGCGAGTTGCTTCTA3'; \\
\hline pur: & F - 5'CTGCTGCGAAAAATCACAAA3', & R - 5'CTCACGATTCGCTGCAATAA3', \\
\hline pycA: & F - 5'GCGTTAGGTGGAAACGAAAG3', & R - 5'CGCGTCCAAGTTTATGGAAT3'; \\
\hline tpi: & F - 5'GCCCAGTAGCACTTAGCGAC3'; & R - 5'CCGAAACCGTCAAGAATGAT3'. \\
\hline
\end{tabular}

$20 \mathrm{sec}$, annealing for $30 \mathrm{sec}$ at $60^{\circ} \mathrm{C}$, and elongation for $20 \mathrm{sec}$ at $72^{\circ} \mathrm{C}$. After 45 cycles, the reaction was completed by the final elongation at $72^{\circ} \mathrm{C}$ for $5 \mathrm{~min}$. PCR products were prepared for sequencing using the BigDye ${ }^{\circledR}$ Terminator v3.1 Cycle Sequencing Kit and BigDye ${ }^{\circledR}$ XTerminator ${ }^{\mathrm{TM}}$ Purification Kit (Applied Biosystems $^{\mathrm{TM}}$ ). DNA sequencing reac- tions were finalised using an $\mathrm{ABI}$ Prism ${ }^{\circledR}$ Genetic Analyzer 3100 sequencer (Applied Biosystems ${ }^{\mathrm{TM}}$ ).

Chromatograms and sequences were exported to BioNumerics Software (Applied Maths, BioMérieux Company) where they were edited, aligned, and compared with the Bacillus cereus group MLST profiles database [35] using the 
recommended tools. Sequences of every fragment of the analysed gene were edited to a suitable length $(g l p F 381 \mathrm{bp}$, gmk 504 bp, ilvD 393 bp, pta 414 bp, pur $348 \mathrm{bp}$, pycA $363 \mathrm{bp}$, and tpi $435 \mathrm{bp}$ ). The allelic profile was arbitrarily assigned for all different sequences, and all identical sequences got the same value. Based on the characteristic profiles of the combination of seven loci, each strain was described by multilocus sequence type (MLST). The dendrograms, showing the genetic relationship between the Bacillus cereus group strains, are based on separate allelic profiles and were constructed using the unweighted pair group method with arithmetic mean (UPGMA).

\section{Results}

The length of the analysed fragments ranged between $348 \mathrm{bp}$ (pur) and $504 \mathrm{bp}$ ( $g m k)$. The average amount of GC bases in the analysed genes fragments ranged from $38.15 \%$ to $44.71 \%$.

As an effect of the analysis obtained by the BioNumerics software, 22 different STs profiles were observed, which had been previously identified in the pubmlst.org database (Table 1). Only once 10 STs (ST1, ST10, ST26, ST34, ST53, ST105, ST206, ST245, ST665, ST972) were identified, 13 strains were recognised to possess STs profile 15 (12 strains of $B$. thuringiensis and one of $B$. cereus), nine strains of transitional environmental strains of Bacillus sp. $B a$ $813+$ possess STs profile 109 . All of the analysed full pathogenic B. anthracis strains have the same STs profile (ST3). However, the vaccination strain $B$. anthracis $34 F 2$ had a different one (ST1). The difference between them resides only in the $g l p F$ gene sequence. Furthermore, some of the transitional environmental strains of Bacillus sp. $\mathrm{Ba}$ $813+$ and $B$. anthracis have the same allelic types of sequences for $g m k$ and pta.

After UPGMA clustering, four major groups were revealed (Figure 1). Cluster $I$ is the most interesting because it includes all analysed $B$. anthracis isolates, both fully pathogenic, and vaccination strains (ST 3 and ST 1) and 13 transitional environmental $B$. $s p$. $B a 813+$ strains (nine with ST109, two with ST163, and two with ST113). All the environmental strains had the same gmk and pta (excluding ST113 and ST163) genes like the analysed B. anthracis strains. Cluster II and III contains a mixture of $B$. cereus, $B$. thuringiensis, and transitional environmental strains, gained from reference collections and isolated from the environment. Cluster III is very interesting because it includes the $B$. thuringiensis strain from the ATCC collection (ST10), two $B$. cereus strains isolated from humans (ST56), and two environmental strains isolated from tooth pulp of dead horses (ST144). In Cluster IV, the one strain of $B$. cereus from the ATCC collection and eight isolates from the environment of $B$. sp. Ba813+ were grouped.

\section{Discussion}

For many years, standard microbiology was the only bacterial identification method and bacteriological diagnostic in medicine. Biological tests with laboratory animals are still recommended by the World Health Organization as a reference method in diagnosis of anthrax (Turnbull 2008). The identification of $B$. anthracis, based on phenotypic features of strains isolated from material derived from the anthrax regarding affirmed cases, never caused a problem. However, after the 1960s, doubtful cases of anthrax diagnosis were described. In those cases, isolated strains from wounds considered anthrax related, 


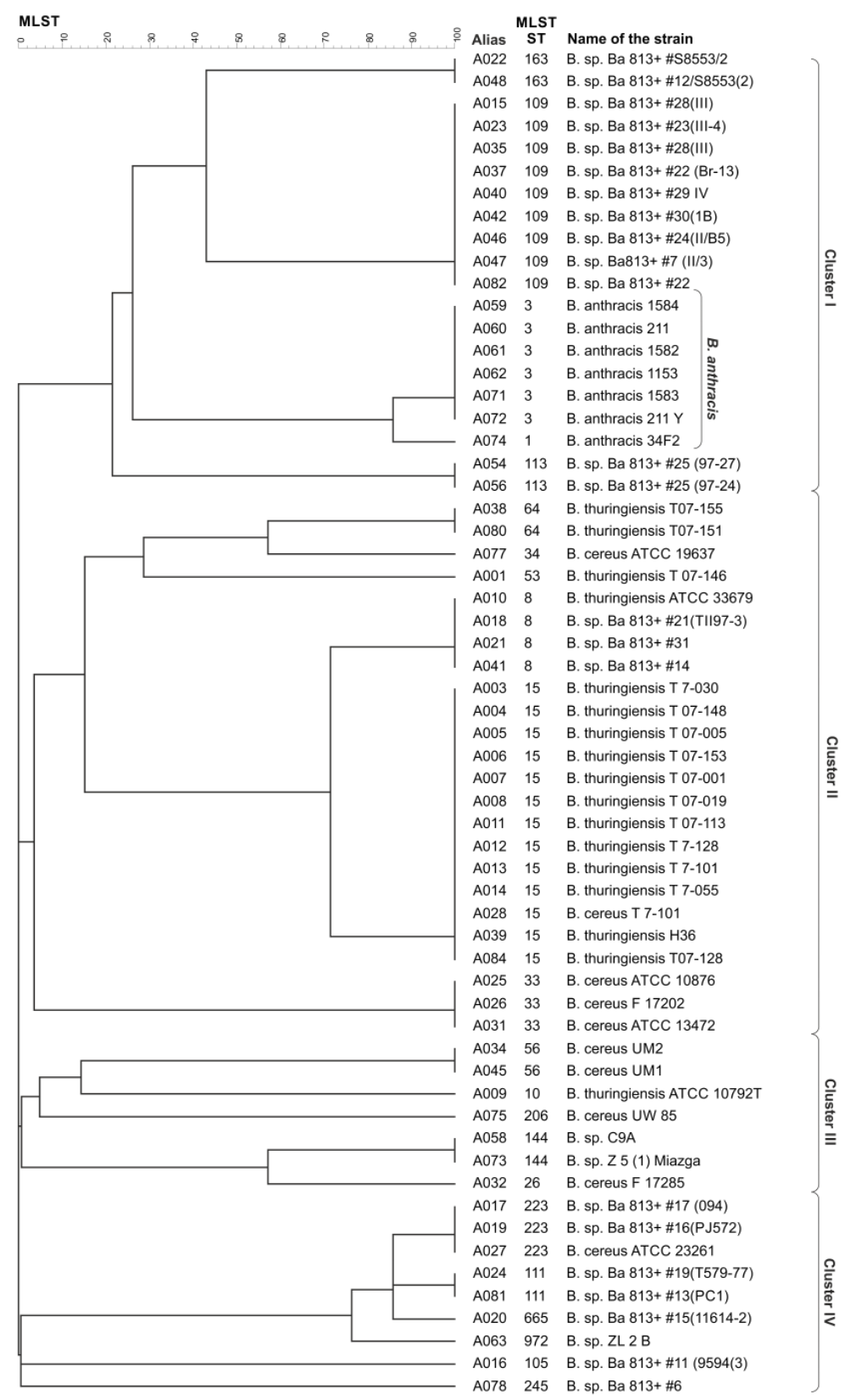

Figure 1. Phylogenetic differentiation of Bacillus cereus group strains clustered by UPGMA method

were identified as B. cereus. Those cases were interpreted as an environmental contamination, as $B$. cereus is present in the natural environment (Turnbull 1999).
Owing to performed genetic studies, this hypothesis has been refuted.

The greater phenotypic identification problem is related to strains isolated from 
the environment, which presents larger biochemical differentiation. Predisposing factors may include a long period of remaining in the spore form and a low protein content in the environment. The occurrence of the cell capsule, which is the characteristic structural element of B. anthracis, depended on the origin of the strains, was also observed. Strains without capsules were isolated from the environment more often than from living organisms (Turnbull 2008).

In relation to the advanced development of molecular biology techniques, phenotypic methods are increasingly being replaced by modern genetic tools. They allow for a rapid and sure analysis and reduce the risk of mistakes in the data interpretation. Furthermore, advanced bioinformatics programmes (e.g., BioNumerics ${ }^{\circledR}$ ) are very useful in interpreting sequencing data from an experiment with a vast group of microorganisms.

In this paper, an MLST experiment based on seven conservative housekeeping genes $(g l p F, g m k$, ilvD, pta, pur, pycA and tpi) was performed. Molecular typing and phylogenetic investigation concerned 60 Bacillus cereus group strains, including $B$. cereus, B. thuringiensis, B. anthracis, and transitional environmental Bacillus spp. strains. This study aimed to identify the exact relationships among the various strains belonging to the common group of Bacillus cereus, including B. anthracis. Close relationships among these strains carry the large risk of their modification from the strains originally nonpathogenic form into a virulent form. In 2003, Radnegde et al. analysed the genetic homology between $B$. anthracis, $B$. cereus, and B. thuringiensis strains isolated from several diverse places (environment, infected people and animals, and contaminated food) using amplified fragment length polymorphism
(Radnedge et al. 2003). This study, employing the MLST technique, confirmed the large genetic homology of the strains comprehended by tests, which also characterised the various places of origin. Tests also showed very large genetic homology among $B$. anthracis, $B$. cereus, and B. thuringiensis. Very similar effects were obtained by Helgason's group in their studies on the different housekeeping genes ( $a d k, c c p A$, ftsA, glpT, pyrE, recF, and sucC) (Helgason et al. 2004).

Cluster I is very interesting from the epidemiological point due to its consistency in including all analysed B. anthracis strains and transitional strains isolated from the environment. The fact that all B. anthracis strains were grouped in one cluster has confirmed a very high level of genetic monomorphism. All of the full pathogenic strains showed the same sequence of analysed gene fragments and as a result, the same sequencing type. The vaccination strain $B$. anthracis $34 \mathrm{~F} 2$ varied only in the sequence of the fragment of glycerol uptake facilitator protein gene. Unfolded differences caused the other ST profile classification.

Analysis of the individual alleles provided the information concerning full homology in the sequences of the gmk and pta genes among B. anthracis, and some transitional environment Bacillus sp. strains. This fact can support the contention that they possess a common ancestor (Patra et al. 1998; Ramisse et al. 1999). Full homology of the sequence of these genes was affirmed by Kim's team (Kim et al. 2005), which provided additional identifying sequences of these genes in some $B$. cereus and $B$. thuringiensis strains. However, similar to our results, Kim's team did not affirm the compatibility of the sequences in all analysed alleles among $B$. anthracis and other representatives of the Bacillus 
cereus group. The examined group in the study included strains, which gave falsepositive results in identifying $B$. anthracis. These results confirmed that MLST is a useful method to differentiate Bacillus cereus strains.

Multilocus sequence typing allows us to define the phylogenetic relationship between closely related strains based on the combination of the sequences of all seven alleles fragments and each of them separately. This characteristic is very important in epidemiological investigations on the potential military/bioterrorist use of B. anthracis. Using this method, the differentiation of $B$. anthracis from other $B$. cereus group strains after genetic modification, e.g., after cloning pXO1 and pXO2 plasmids, is possible. The MLST method is also very useful when the sequence of virulent genes (localised on plasmids) in material from people with anthrax symptoms can't be detected using typical molecular techniques (e.g., PCR). The false-negative results of PCR sometimes can be caused by the mutation changes in the target spaces during annealing (Turnbull et al. 1992).

\section{References}

Bolt, F., Cassiday, P., Tondella, M.L., Dezoysa, A., Efstratiou, A., Sing, A., Zasada, A., Bernard, K., Guiso, N., Badell, E., Rosso, M.-L., Baldwin, A., Dowson, C. 2010. Multilocus sequence typing identifies evidence for recombination and two distinct lineages of Corynebacterium diphtheriae. Journal of Clinical Microbiology, 48: 4177-4185.

Brossier, F., Mock, M. 2001. Toxins of Bacillus anthracis. Toxicon, 39(11): 1747-1755.

Centers for Disease Control and Prevention 2017. Emergency Preparedness and Response - Bioterrorism Agents/Diseases. Available at https://emergency.cdc.gov/agent/agentlistcategory.asp. Accessed 7.09.2017.

Chang, B., Wada, A., Hosoya, M., Oishi, T., Ishiwada, N., Oda, M., Sato, T., Terauchi, Y., Okada, K., Nishi, J., Akeda, H., Kamiya, H., Ohnishi, M., Ihara, T., Japanese Invasive Disease Study Group, 2014. Characteristics of group B streptococcus isolated from infants with invasive infections: a population-based study in Japan. Japanese Journal of Infectious Diseases, 67: 356-360.

Cherif, A., Borin, S., Rizzi, A., Ouzari, H., Boudabous, A., Daffonchio, D. 2003. Bacillus anthracis diverges from related clades of the Bacillus cereus group in $16 \mathrm{~S}-23 \mathrm{~S}$ ribosomal DNA intergenic transcribed spacers containing tRNA genes. Applied and Environmental Microbiology, 69: 33-40.

Cieślik, P., Knap, J., Kołodziej, M., Mirski, T., Joniec, J., Graniak, G., Żakowska, D., Winnicka, I., Bielawska-Drózd, A. 2015. Realtime PCR identification of unique Bacillus anthracis sequences. Folia Biologica (Praha), 61(5): 178-183.

DeVos, P., Hogers, R., Bleeker, M., Reijans, M., van de Lee, T., Hornes, M., Frijters, A., Pot, J., Peleman, J., Kuiper, M., Zabeau, M. 1995. AFLP: a new technique for DNA fingerprinting. Nucleic Acids Research, 23: 4407-4414.

Diavatopoulos, D.A., Cummings, C.A., Schouls, L.M., Brinig, M.M., Relman, D.A., Mooi, F.R. 2005. Bordetella pertussis, the causative agent of whooping cough, evolved from a distinct, human-associated lineage of $B$. bronchiseptica. PLoS Pathogens, 1(4): e45. Doi: https://doi.org/10.1371/journal.ppat.0010045.

Duan, R., Liang, J., Shi, G., Cui, Z., Hai, R., Wang, P., Xiao, Y., Li, K., Qiu, H., Gu, W., Du, X., Jing, H. 2014. Homology analysis of pathogenic Yersinia species Yersinia enterocolitica, Yersinia pseudotuberculosis, and Yersinia pestis based on multilocus sequence typing. Journal of Clinical Microbiology, 52: 20-29.

Elleuch, J., Zghal RZ, Jemaà, M., Azzouz, H., Tounsi, S., Jaoua, S. 2014. New Bacillus thuringiensis toxin combinations for biological control of lepidopteran larvae. International Journal of Biological Macromolecules, 65: $148-154$.

Frederiksen, K., Rosenquist, H., Jørgensen, K., Wilcks, A. 2006. Occurrence of natural Bacillus thuringiensis contaminants and residues of Bacillus thuringiensis-based insecticides on fresh fruits and vegetables. Applied and Environmental Microbiology, 72: 3435-3440.

Gierczyński, R. 2010. Diagnostics and molecular epidemiology of Bacillus anthracis. Postępy Mikrobiologii, 49(3): 165-172 (in Polish).

Helgason, E., Caugant, D.A., Olsen, I., Kolstø, A.B. 2000a. Genetic structure of population of Bacillus cereus and B. thuringiensis isolates associated with periodontitis and other human infections. Journal of Clinical Microbiology, 38: 1615-1622. 
Helgason, E., Okstad, O.A., Caugant, D.A., Johansen, H.A., Fouet, A., Mock, M., Hegna, I., Kolstø, A.B. 2000b. Bacillus anthracis, Bacillus cereus, and Bacillus thuringiensis - one species on the basis of genetic evidence. Applied and Environmental Microbiology, 66: 2627-2630.

Helgason, E., Tourasse, N.J., Meisal, R., Caugant, D.A., Kolstø, A.B. 2004. Multilocus sequence typing scheme for bacteria of the Bacillus cereus group. Applied and Environmental Microbiology, 70: 191-201.

Hoffmaster, A.R., Hill, K.K., Gee, J.E., Marston, C.K., De, B.K., Popovic, T., Sue, D., Wilkins, P.P., Avashia, S.B., Drumgoole, R., Helma, C.H., Ticknor, L.O., Okinaka, R.T., Jackson, P.J. 2006. Characterization of Bacillus cereus isolates associated with fatal pneumonias: strains are closely related to Bacillus anthracis and harbor $B$. anthracis virulence genes. Journal of Clinical Microbiology, 44: 3352 3360 .

Kim, K, Cheon, E., Wheeler, K.E., Youn, Y., Leighton, T.J., Park, C., Kim, W., Chung S.-I. 2005. Determination of the most closely related Bacillus isolates to Bacillus anthracis by multilocus sequence typing. Yale Journal of Biology and Medicine, 78: 1-14.

Kim, J.B., Jeong, H.R., Park, Y.B., Kim, J.M., Oh, D.H. 2010. Food poisoning associated with emetic-type of Bacillus cereus in Korea. Foodborne Pathogens and Disease, 7: 555-563.

Ludwig, W., Schleifer, K.H., Whitman, W.B. 2009. Revised road map to the phylum Firmicutes. In: Bergey's manual of systematic bacteriology. Vol. 3 (DeVos, P., Garrity, G., Jones, D., Krieg, N.R., Ludwig, W., Rainey, F.A., Schleifer, K.-H., Whitman, W. eds), Springer, New York; pp 1-128.

Maiden, M.C., Bygraves, J.A., Feil, E., Morelli, G., Russell, J.E., Urwin, R., Zhang, Q., Zhou, J., Zurth, K., Caugant, D.A., Feavers, I.M., Achtman, M., Spratt, B.G. 1998. Multilocus sequence typing: a portable approach to the identification of clones within populations of pathogenic microorganisms. Proceedings of the National Academy of Sciences USA, 93: 3140-3145.

Økstad, O.A., Kolstø, A.B. 2011. Chapter 2 Genomics of Bacillus Species. Genomics of Foodborne Bacterial Pathogens. Food Microbiology and Food Safety, 29-53.

Olsen, J.S., Scholz, H., Fillo, S., Ramisse, V., Lista, F., Trømborg, A.K., Aarskaug, T., Thrane, I., Blatny, J.M. 2014. Analysis of the genetic distribution among members of Clostridium botulinum group I using a novel multilocus sequence typing (MLST) assay. Journal of Microbiological Methods, 96: 84-91.
Patra, G., Vaissaire, J., Weber-Levy, M., Le Doujet, C., Mock, M. 1998. Molecular characterization of Bacillus strains involved in outbreaks of anthrax in France in 1997. Journal of Clinical Microbiology, 36: 3412-3414.

Priest, F.G., Barker, M., Baillie, L.W., Holmes, E.C., Maiden, M.C. 2004. Population structure and evolution of the Bacillus cereus group. Journal of Bacteriology, 186: 7959-7970.

PubMLST. 2018. Bacillus cereus MLST Databases. Available at https://pubmlst.org/bcereus/. Accessed 24.07.2018

Radnedge, L., Agron, P.G., Hill, K.K., Jackson, P.J., Ticknor, L.O., Keim, P., Andersen, G.L. 2003. Genome differences that distinguish Bacillus anthracis from Bacillus cereus and Bacillus thuringiensis. Applied and Environmental Microbiology, 69: 2755-2764.

Ramisse, V., Patra, G., Vaissaire, J., Mock, M. 1999. The Ba813 chromosomal DNA sequence effectively traces the whole Bacillus anthracis community. Journal of Applied Microbiology, 87: 224-228.

Selander, R.K., Caugant, D.A., Ochman, H., Musser, J.M., Gilmour, M.N., Whittam, T.S. 1986. Methods of multilocus enzyme electrophoresis for bacterial population genetics and systematics. Applied and Environmental Microbiology, 51: 873-884.

Singh, P.K., Ramachandran, G., Ramos-Ruiz, R., Peiró-Pastor, R., Abia, D., Wu, L.J., Meijer, W.J.J. 2013. Mobility of the native Bacillus subtilis conjugative plasmid pLS20 is regulated by intercellular signaling. PLoS Genetics, 9(10): e1003892. Doi: https://doi.org/10.1371/journal.pgen.1003892.

Skaare, D., Anthonisen, I.L., Caugant, D.A., Jenkins, A., Steinbakk, M., Strand, L., Sundsfjord, A., Tveten, Y., Kristiansen B.-E. 2014. Multilocus sequence typing and ftsI sequencing: a powerful tool for surveillance of penicillin-binding protein 3-mediated betalactam resistance in nontypeable Haemophilus influenzae. BMC Microbiology, 20: 14, 131. Doi: https://doi.org/10.1186/1471-2180-14131.

Sorokin, A., Candelon, B., Guilloux, K., Galleron, N., Wackerow-Kouzova, N., Ehrlich, S.D., Bourguet, D., Sanchis, V. 2006. Multiple-locus sequence typing analysis of Bacillus cereus and Bacillus thuringiensis reveals separate clustering and a distinct population structure of psychrotrophic strains. Applied and Environmental Microbiology, 72: 1569-1578.

Soufiane, B., Côté, J.C. 2013. Bacillus weihenstephanensis characteristics are present in Bacillus cereus and Bacillus mycoides strains. FEMS Microbiology Letters, 341: 127-137.

Souza, R,A, Imori, P.F., Passaglia, J., PitondoSilva, A., Falcão, J.P. 2013. Molecular typing 
of Yersinia pseudotuberculosis strains isolated from livestock in Brazil. Genetics and Molecular Research, 12: 4869-4878.

Svensson, B., Monthán, A., Guinebretière, M.H., Nguyen-Thé, C., Christiansson, A. 2007. Toxin production potential and the detection of toxin genes among strains of the Bacillus cereus group isolated along the dairy production chain. International Dairy Journal, 17: 12011208.

Tenover, F.C., Arbeit, R.D., Goering, R.V., Mickelsen, P.A., Murray, B.E., Persing, D.H., Swaminathan, B. 1995. Interpreting chromosomal DNA restriction patterns produced by pulsed-field gel electrophoresis: criteria for bacterial strain typing. Journal of Clinical Microbiology, 33: 2233-2239.

Tenover, F.C., Arbeit, R.D., Goering, R.V. 1997. How to select and interpret molecular strain typing methods for epidemiological studies of bacterial infections: a review for healthcare epidemiologists. Molecular Typing Working Group of the Society for Healthcare Epidemiology of America. Infection Control \& Hospital Epidemiology, 18: 426-439.

Thorsen, L., Hansen, B.M., Nielsen, K.F., Hendriksen, N.B., Phipps, R.K., Budde, B.B. 2006. Characterization of emetic Bacillus weihenstephanensis, a new cereulide-producing bacterium. Applied and Environmental Microbiology, 72: 5118-5121.
Ticknor, LO, Kolstø, A.B., Hill, K.K., Keim, P., Laker, M.T., Tonks, M., Jackson, P.J. 2001. Fluorescent amplified fragment length polymorphism analysis of norwegian Bacillus cereus and Bacillus thuringiensis soil isolates. Applied and Environmental Microbiology, 67: 4863-4873.

Turnbull, P., Hutson, R.A., Ward, M.J., Jones, M.N., Quinn, C.P., Finnie, N.J., Duggleby, C.J., Kramer, J.K., Melling, J. 1992. Bacillus anthracis but not always anthrax. Journal of Applied Microbiology, 72: 21-28.

Turnbull, P. 1999. Definitive identification of Bacillus anthracis - a review. Journal of Applied Microbiology, 87: 237-240.

Turnbull, P. 2008. Anthrax in humans and animals. 4th ed. World Health Organization. Geneva.

Zhou, H., Zhao, X., Wu, R., Cui, Z., Diao, B., Li, J., Wang, D., Kan, B., Liang, W. 2014. Population structural analysis of $\mathrm{O} 1 \mathrm{El}$ Tor Vibrio cholerae isolated in China among the seventh cholera pandemic on the basis of multilocus sequence typing and virulence gene profiles. Infection, Genetics and Evolution, 22: 72-80.

Zhou, Y., Burnham, C.A., Hink, T., Chen, L., Shaikh, N., Wollam, A., Sodergren, E., Weinstock, G.M., Tarr, P.I., Dubberke, E.R. 2014. Phenotypic and genotypic analysis of Clostridium difficile isolates: a single center study. Journal of Clinical Microbiology, 52: 4260-4266. 